\title{
CONSTRUCTIVE DIVIDENDS: TAXING THE WAIVING SHAREHOLDER TO THE EXTENT OF DIVIDENDS WAIVED
}

The Internal Revenue Service has established a policy of applying the constructive dividend doctrine when a shareholder waives his right to future undeclared dividends, where no bona fide business purpose exists for the waiver and where the benefited shareholder is a relative of the waiving shareholder. The Service has neither designated the business purposes which are to be regarded as legitimate nor announced what policy will prevail where both a bona fide business purpose and a substantial benefit to the waiving shareholder's relatives exist. However, case law in analogous tax areas indicates that the constructive dividend doctrine will not be applied where the business purpose is bona fide, even though the waiver also benefits relatives of the waiving shareholder.

\section{I}

NASMUCH as the prospective waiver of future undeclared dividends by some shareholders of a corporation amounts to a shifting of income among taxpayers, the Internal Revenue Service has sought to tax such shareholders as recipients of a constructive dividend on their pro rata share of waived dividends, ${ }^{1}$ except when the dividends were waived for a bona fide business purpose. ${ }^{2}$ This exception was first

\footnotetext{
${ }^{1}$ In order to tax such diversions of corporate earnings to a shareholder's benefit, courts developed the doctrine of constructive dividends. See, e.g., Sachs v. Commissioner, 277 F.2d 879 (8th Cir.), cert. denied, 364 U.S. 833 (1960). See generally Brafford, The Constructive Receipt of Dividends by Stockholders of a Closely Held Corporation (pt. I), 46 KY. L.J. 515 (1958); (pts. 2-3), 47 Ky. L.J. 17, 378 (1958-59). Much of the force behind the constructive dividend doctrine is found in dicta enunciated in the famous case of Helvering v. Horst, 311 U.S. 112 (1940), where Mr. Justice Stone announced that "the power to dispose of income is the equivalent of ownership of it. The exercise of that power to procure the payment of income to another is the enjoyment, and hence the realization of income by him who exercises it." Id. at 118 . On the basis of Horst it appears that when one shareholder waives his right to dividends, he may be taxed to the extent of the dividends waived. Such a waiver may result in either increased dividends to other shareholders or an increase in the corporate surplus which thereby increases the value of the corporate stock of all shareholders. In either instance, however, the shareholder has "disposed" of "his power to have received such funds." See Byers v. Commissioner, 199 F.2d 273, $275-76$ (8th Cir. 1952), cert. denied, 345 U.S. 907 (1953).

2 See Rev. Rul. 65-256, 1965 INT. Rev. Bur.. No. 46, at 27; Rev. Rul. 56-431, 1956-2 Cum. Bull. 171; Rev. Rul. 45, 1953-1 Cum. Bull. 178.

A precondition to applying the doctrine of constructive dividends is a finding of "earnings and profits" of the corporation which are at least equal to the amount of the distribution being taxed. Helvering v. Gordon, 87 F.2d 663, 667 (8th Gir. 1937). See INT. REv. CODE OF 1954, § 316 (a).
} 
recognized by the Service in 1953 in Revenue Ruling $45,{ }^{3}$ where the waiver was made for the purpose of building up surplus to enable the corporation to meet certain legal requirements regarding contemplated business needs and where there existed no direct family or business relationship between the waiving and non-waiving shareholders. ${ }^{4}$ Revenue Ruling 56-4315 limited the application of this exception, however, to the situation where the alleged business purpose of paying a larger dividend to minority shareholder-employees to maintain their good will while averting a depletion of the corporation's working capital. The Service characterized this situation as producing a merely incidental corporate benefit since over seventy-one per cent of the non-waiving shares were held by relatives of the waiving shareholder. Only twenty-nine per cent of the shares which paid dividends were held by employees of the corporation. ${ }^{6}$

The bona fide business purpose exception to the constructive dividend doctrine was recently reaffirmed in Revenue Ruling 65-256. That ruling involved a situation in which the majority shareholder of one of two merging corporations waived a substantial portion of the dividends for three immediately subsequent years in order to induce the shareholders of the other merging corporation to agree to the merger, to obtain voting control of the surviving corporation and to preserve its working capital. Relatives of the waiving shareholder who benefited from the waiver held an interest in the surviving corporation, but only to the extent of 0.06 per cent. The Service ruled that because the waiver was supported by a bona fide business purpose and resulted in only insignificant benefits

3 1953-1 Cum. Bulr. 178.

- The existence of a family relationship between parties to a transaction offers op. portunities for tax avoidance schemes because of the mutual trust and informal cooperation inherent in such a relationship. SURREY \& WARREN, FEDERAL Income Taxation 939-40 (1962); see, e.g., Byers v. Commissioner, 199 F.2d 273-74 (8th Cir. 1952), cert. denied, 345 U.S. 907 (1953). When no direct family relationship is involved, the likelihood that legitimate business reasons have guided the transaction is greatly increased.

1956-2 CuM. BuLL. 171.

- Rev. Rul. 56-431, 1956-2 Cum. Bull. 171, 172.

Although the Service characterized the "primary purpose" for the waiver as an attempt to accord benefits to the taxpayer's relatives, the ruling appeared to make no inquiry into motivation or intent. Rather, in assessing the "primary purpose" of the waiver, the Service ostensibly applied an objective test of net economic benefit based on all the circumstances. See 1956-2 Cum. BuLl. at 172-73.

7 I965 INT. Rev. BuLI. No. 46, at 27. 
to the waiving shareholder's relatives, it would not cause the waiving shareholder to receive any constructive dividends. ${ }^{8}$

These three revenue rulings establish a Service policy of applying the constructive dividend doctrine in situations where no bona fide business purpose exists to justify the waiver and where the benefited shareholder is a relative of the waiving shareholder. But the rulings do not spell out exactly what purposes are bona fide business purposes, nor do they indicate whether the exception prevails in cases where both a bona fide business purpose and a substantial benefit to the waiving shareholder's relatives exist. The taxpayer must seek an answer to these problems in the case law of analogous tax areas.

One area in which the business purpose exception has arisen involves the income tax allocation of a waiver of future dividends in order to obtain voting power through purchase of non-waiving shares. In Tucker $v$. Commissioner, ${ }^{\circ}$ an automobile manufacturer required the managers of corporations holding dealer franchises to acquire controlling interests therein. In order to induce an unrelated minority shareholder to sell his stock and to thereby acquire a controlling interest, the manager-taxpayer in Tucker agreed to cause the corporation to pay twenty per cent of its profits for the following five years to the minority shareholder. Despite the objections of the Commissioner, these payments of corporate earnings were held not to constitute constructive dividends to the manager. ${ }^{10}$ The Tucker holding indicates that an exchange of future dividends for voting power in order to preserve one of the corporation's most valuable assets will be viewed as a transaction consummated for a bona fide business purpose in situations where the parties involved bargain at arm's length. ${ }^{11}$

\footnotetext{
${ }^{8}$ Rev. Rul. 65-256, 1965 INT, Rev. Buld. No. 46, at 28.

- 226 F.2d 177 (8th Cir. 1955).

${ }^{10}$ Id. at 179.

11 Not only has the preservation of a corporation's most valuable asset been held to be a legitimate corporate purpose, but in Williams \& Waddell, Inc. v. Pitts, 148 F. Supp. 778 (E.D.S.C. 1957), the court upheld as ordinary and necessary business expenses payments made by the corporation to induce a shareholder to sell her shares so that a corporate deadlock could be resolved, thereby enabling the corporation to function as an operative business concern. In Pitts, one of the two corporate shareholders had died, leaving his fifty per cent stock interest to his wife. A deadlock ensued concerning who was to be the deceased's replacement in the business, and the widow finally agreed to sell her stock to a buyer acceptable to all parties concerned. As consideration in addition to the purchase price, the corporation was required to pay the widow one hundred dollars monthly for life. These monthly
} 
The Tucker rule seemingly is not limited to the situation where the waiving and non-waiving shareholders are unrelated. In Majorie $N$. Dean ${ }^{12}$ the shareholders of a corporation had adopted a plan whereby women who inherited voting stock in the corporation had the option to surrender that stock in exchange for non-voting cumulative preferred stock upon profitable terms. The purpose of the plan was to induce inexperienced women shareholders to forego attempts to become involved in the management of the corporation, thereby placing the corporation in a better position to attract new executive talent. ${ }^{13}$ The court held that the plan qualified as nontaxable reorganization ${ }^{14}$ although it involved provisions which were equivalent to a partial waiver of future dividends on the part of the remaining holders of voting stock, since the preferred stock was to receive a greater proportionate share of dividends. Significantly, Dean involved a direct family relationship, as two of the women receiving dividend preference were the sister and niece of the corporation's chief executive officer, the latter holding only non-preferred shares in the corporation..$^{15}$

Similar to the exchange of dividend rights for voting rights is a waiver of future dividends by one shareholder to enable another shareholder to sell out to a new party and thus avert corporate liquidation. The case of United States $v$. Carey ${ }^{18}$ provides some support for the contention that this transaction represents a valid business purpose and thus would not subject the waiving shareholder to tax liability under the constructive dividend doctrine. In Carey, two equal shareholders of a corporation effected a pro rata redemption of a large portion of capital stock to enable the only available buyer, who otherwise had insufficient funds, to purchase the stock interest of the retiring shareholder. ${ }^{17}$ Under these circumstances the Eighth

payments were held to be deductible by the corporation as "ordinary and necessary" business expenses and were not taxable to the remaining shareholder as a constructive dividend. Id. at $779-81$.

1210 T.C. 19 (1948).

${ }^{13}$ Id. at $21-22$.

14 To qualify as a nontaxable reorganization under sections 354 (a) and 368 (a) of the Internal Revenue Code of 1954, the reorganization must be for a bona fide business purpose. See Gregory v. Helvering, 293 U.S. 465, 469 (1935).

${ }^{16} 10$ T.C. at 22.

28 289 F.2d 531 (8th Cir. 1961).

${ }^{27} I d$. at 532-33. By virtue of this pro rata redemption the capital structure of the corporation was sufficiently decreased to enable an outsider to purchase a $49.4 \%$ interest in the corporation's outstanding stock at a greatly reduced price. Ibid. 
Circuit found a bona fide business purpose and held that the pro rata redemption was not taxable as a distribution essentially equivalent to a dividend. ${ }^{18}$ On the other hand, had the selling shareholder individually redeemed a portion of his stock at a price in excess of market value, ${ }^{19}$ a constructive dividend might have been attributed to the remaining shareholder since his agreement to the redemption amounts to a waiver of his dividend rights in the corporate surplus used to meet that portion of the redemption price which exceeds the market value of the shares. ${ }^{20}$ As in Carey, however, the corporate purpose in this situation seems clear. If the remaining shareholder does not agree to the unilateral redemption, the corporation's existence is jeopardized. Therefore, by applying the Carey rationale the excess would not be taxed to the waiving shareholder as a constructive dividend. ${ }^{21}$

It is arguable that a rule which permits the waiver of dividends to achieve a change of shareholders for a bona fide corporate purpose without incurring the application of the constructive dividend doctrine should apply even where the parties involved are directly

\footnotetext{
${ }^{18}$ Id. at 538-39. Section 302 (a) of the Internal Revenue Code of 1954 treats a corporate stock redemption as a distribution in exchange for stock and thus accords capital gains treatment to the transaction. Section $302(\mathrm{~b})$, however, excludes from such treatment those redemptions of stock which are "essentially equivalent to a dividend." If section 302 (b) applies, gain to the shareholder on the transaction is treated as ordinary income. Id. at 535. See generally BITTKER, Federal Income TAXaTION OF CoRporations AND Shareholders 223-34 (student ed. 1959).

10 See note 20 infra.

Perhaps the shareholder who remains with the corporation might decide that the maintenance of a certain surplus was essential to the welfare of the corporation and that a pro rata redemption would impair that surplus. Accordingly, the selling shareholder might individually redeem a portion of his stock and sell only his remaining unredeemed stock to the incoming shareholder.

${ }^{20}$ Carey involved a close corporation and there was no true market value for the shares. This is evidenced by the fact that no interested buyer could be found at $\$ 50,000$, the price at which the selling shareholder valued his stock interest. Thus the use of the term "market value" in this context indicates the value which the shareholders themselves place upon their stock interest in the corporation. See 289 F.2d at 532.

${ }^{21}$ Analogous to the waiver of dividend problem presented by Revenue Ruling 65-256 is the situation where a shareholder who desires to retain an interest in the corporation agrees to waive his right to dividends for a period of years in order to induce a third party to buy out the stock interest of a retiring shareholder at a price in excess of market value. The incoming shareholder is induced to purchase the stock at a higher price because the waiver of dividends by the shareholder who remains with the corporation will result in a larger proportional distribution of dividends to the shares purchased. If no other buyer can be found who is willing to purchase the stock at the seller's price, a bona fide business purpose arguably exists under the Carey rationale, since the only alternative open' to the selling shareholder may be to cause the corporation to be liquidated.
} 
related. In Fred F. Fischer ${ }^{22}$ a minority shareholder, a sister of the majority shareholder, threatened to institute receivership proceedings against the corporation and to file a suit contesting the will of the father of both shareholders and the former manager of the corporation. To avert this action, the majority shareholder caused the corporation to redeem his sister's stock at a price in excess of its book value in release of all her claims against the corporation, its shareholders and directors. ${ }^{23}$ The court held that the excess paid the sister above the book value of the stock was not taxable to the remaining shareholders as a constructive dividend. ${ }^{24}$ According to the court, the corporation was serving an interest of its own "for the purpose of promoting harmony in the conduct of the business and securing it from annoying interference and threats of legal proceedings."25 The fact that the redemption conferred a substantial, independent benefit on the remaining shareholders did not discredit this bona fide corporate "interest." 20

Another situation in which the business purpose exception can arise was presented to the Sixth Circuit in Nelson $v$. Commissioner, ${ }^{27}$ In that case payments were made by a corporation to a minority shareholder, who was the mother of the corporation's president and majority shareholder, in exchange for the use of a secret process and an unpatented invention which was valuable in the

\footnotetext{
2216 P-H Tax Ct. Mem. 456 (1947).

${ }^{23}$ Id. at 457-59. An unarticulated factor in the court's decision was perhaps the fact that although the shareholders were related, their positions were distinctly adverse. Ibid.; see note 29 infra.

24 Arguably, a constructive dividend could theoretically be attributed to the shareholders in this situation. The corporation paid the excess of the redemption price over the book value from corporate earnings or surplus which might otherwise have been distributed as dividends to the shareholders. Since the shareholders approved of the payment made for the redeemed stock, $16 \mathrm{P}-\mathrm{H}$ Tax Ct. Mem. at 458, they effectively waived their right to receive this amount as a dividend distribution in favor of the additional purchase price paid to the minority shareholder.

${ }^{25} I d$. at 460 . For the constructive dividend doctrine to apply, the relative receiving the financial benefit need not be a shareholder. For example, in Minnie F. Lasker, 21 P-H Tax Ct. Mem. 40 (1952), a mother, who was president and owner of ninety per cent of the common stock in a corporation, authorized a disbursement to her daughter, who was not a shareholder, in order to prevent a possible family dispute. The court found that the payment had not been made for a bona fide business purpose and taxed it to the mother on a constructive dividend theory. Id. at 40.41 . This case need not be viewed as inconsistent with the result in Fischer since the benefited relative was not a shareholder and thus not in a position to threaten corporate dissolution. Absence of this factor lessens the likelihood of the existence of a bona fide business purpose for the disbursement.

2016 P-H Tax Ct. Mem. at 459-60.

27203 F.2d 1 (6th Cir. 1953).
} 
corporation's manufacturing operations. ${ }^{28}$ Although the effect of the payments was similar to a waiver of dividends by the majority shareholders to a minority shareholder-relative, the court refused to impute dividends to the waiving shareholders. The court in Nelson did not consider the benefit accruing to a waiving shareholder's relative significant once a legitimate business purpose had been found. Rather, the court stated that "regardless of his affectionate motive and inducement of generosity on the part of the corporation toward his mother," the family relationship factor could not serve to invalidate a transaction that was otherwise "lawfully impeccable."29 Exactly what the court meant by its use of this term is not clear, 30 but the Nelson opinion clearly indicates that no constructive dividend will result when future dividends are waived as payment to a related shareholder who contributes a valuable asset in consideration of the waiver, since the purpose for the waiver meets the business purpose exception.

Another business purpose which a court has recognized as bona fide was articulated in Ruben $v$. Commissioner, ${ }^{31}$ where a corporation settled a claim on which both the corporation and its three shareholders were jointly and severally liable. The Eighth Circuit held that there was no constructive dividend to Ruben, one of the three shareholders, as the corporation had "its own interest to serve and ... gained affirmative advantages through a compromise settlement."32

The question of constructive dividends would also arise in the Ruben context where a corporation paid a judgment on which fewer

${ }^{9}$ Id. at 3. The president held $66.4 \%$ of the stock, his brother held $30.8 \%$ and his mother held $1.2 \%$. Ibid.

"Id. at 6-7. When the potentialities for family cooperation are clearly absent, as in Fischer, and the interests of the related parties are plainly adverse, judicial suspicion aroused by the family relationship is ameliorated and the "family relationship doctrine" loses its force. On the other hand, it is arguable that the family relationship should be a more controlling factor where harmony exists in situations such as Nelson. See note 4 supra. In sum, the tenor of family relationship is thus only a quantum in the factual determination of a legitimate business purpose and its impact will vary with the situation.

${ }^{30}$ The court appeared to use the term in the sense of equivalence in objective value received by the corporation in consideration for its payments. See $203 \mathrm{~F} .2 \mathrm{~d}$ at $\mathbf{5}-6$. The meaning of consideration in this context is probably limited to its objective rather than its subjective sense; that is, a consideration yielding a substantial corporate benefit in fact. In Nelson, for example, the secret process which the corporation received was used in manufacturing various items in the regular course of its business, which items constituted the great bulk of its sales. Id. at 1-2.

s1 97 F.2d 926 (8th Cir. I938).

so Id. at 929. 
than all the shareholders were liable jointly with the corporation. In such a case the Commissioner might view payment as analogous to a waiver of dividends by the non-liable shareholders for the benefit of the liable shareholders. Yet it would appear that since the corporation has "its own interest to serve" and would gain "affirmative advantages" from payment, such a waiver would be for a bona fide business purpose and would not constitute a constructive dividend to the waiving shareholders. This would seemingly hold true even where the waiving and non-waiving shareholders were directly related because the same benefit accrues to the corporation in either case. $^{33}$

A fifth type of bona fide business purpose which emerges from an examination of the case law is the funding of shareholder stock purchase arrangements through corporate payment of insurance premiums on the lives of shareholders. In Prunier v. Commissioner $^{34}$ the question of a constructive dividend arose when a corporation insured the lives of its two shareholders, the proceeds to be used by the corporation to purchase the stock interest of whichever shareholder died first. In Prunier the two shareholders were brothers, each of whom owned equal stock interest in the corporation. ${ }^{35}$ The First Circuit found that no constructive dividend would be attributed to either shareholder. The court acknowledged that such a funding plan served legitimate business purposes by tending to stabilize the corporation to obtain credit and by inducing key employees to remain with the corporation..$^{36}$

\footnotetext{
${ }^{33}$ Where the corporation is not jointly liable with the shareholders, payment by it would clearly constitute a constructive dividend. Such a situation arose in Sachs v. Commissioner, 277 F.2d 879 (8th Cir. 1960), where a corporation was owned by four brothers and a non-relative, one of the brothers holding a one-third stock interest and serving as the corporation's president. When a fine was incurred by the president as a result of efforts to evade corporate income taxes, the corporation adopted a resolution that it pay the fine. The court found that the payment was made solely for the president's benefit and held that a constructive dividend accrued to the president in the absence of any liability on the part of the corporation. Id. at 880-81, 883-84. As the president was the controlling shareholder, the court did not consider taxing the remaining, related shareholders on the waiver theory.

${ }^{34} 248$ F.2d 818 (Ist Cir. 1957).

ss $I d$. at 819.

${ }^{30} \mathrm{Id}$. at 822. Compare Emeloid Co. v. Commissioner, 189 F.2d 230 (3d Cir. 1951) (stock purchase agreement held to be a bona fide business purpose in cxcess profits tax context).

Stock purchase agreements funded by insurance policies on the lives of the corporation's shareholders are commonplace in close corporations. See, e.g., Sanders v. Fox, 253 F.2d 855 (10th Cir. 1958). The stock funding plan makes the close corpora. tion a much more attractive form of business arrangement. Since the insurance pro-
} 
Where one of the two shareholders is significantly older than the other, such insurance payments by the corporation might be viewed as a waiver of dividends by the older shareholder. Arguably the payment of premiums by the corporation accrues primarily to the benefit of the younger shareholder, while the older shareholder is actually sharing the expense of the purchase price by waiving his right to receive a proportionate share of the premium payments as dividends. ${ }^{37}$ In Revenue Ruling $59-184^{38}$ the Service stated that it will follow the Prunier decision in this context, thereby tacitly accepting such insurance funding plans as bona fide despite a significant benefit to a waiving shareholder's relative. ${ }^{39}$

Retirement plans, on the other hand, have not been accorded the same tax benefit extended to stock purchase plans. In GlennMinnich Clothing Co., ${ }^{40}$ the corporation's stock was equally owned by three shareholders, two of whom were brothers. ${ }^{41}$ When the three, all of whom were approaching retirement age, failed to agree on a company retirement plan, one of the brothers agreed to sell his stock to the two remaining shareholders for eighty thousand dollars. As additional consideration, the corporation was to pay twenty thousand dollars in retirement pay to the selling shareholder and his

ceeds can be used to purchase the interest of the deceased shareholder, corporate continuity, freedom from interference by potentially disruptive outsiders and general corporate stability are furthered. 248 F.2d at 822.

${ }^{37}$ Although such an arrangement clearly benefits the older shareholder by assuring a ready market for his shares, this benefit would appear to be outweighed by benefits accruing to the younger shareholder. By corporate funding of the stock purchase plan, the older shareholder is, in effect, sharing the expense of the higher insurance premiums on his life as well as the cost of his stock upon his death. The stock interest of the younger shareholder in the corporation is thereby greatly increased at only a nominal cost and the appeal to a young businessman of the close corporation as a form of business entity is greatly enhanced. See note 36 supra. Thus, the benefits to the younger shareholder from such a funding arrangement extend significantly beyond the older shareholder's death.

${ }^{38}$ 1959-1 Cunr. Bull. 65.

${ }^{30}$ The Fifth Circuit in Paramount-Richards, Inc. v. Commissioner, 153 F.2d 602 (5th Cir. 1946), did not approve a similar stock funding plan which ran primarily to the shareholders' benefit and only incidentally benefited the corporation. In that case the insurance proceeds were intended to adjust the purchase price of the stock in the event that a stock option was exercised. Thus the premium payments were deemed to be merely an appropriation of corporate funds to the shareholders' benefit. Id. at 604. Rev. Rul. 59-184, 1959-1 CuM. Bull. 65, follows the Paramount result and approves such a stock purchase plan to the extent that "the right of the beneficiary to receive the proceeds is conditioned upon the transfer of the corporate stock to the corporation." Id. at 68. See SURREY \& WARREN, op. cit. supra note 4, at 1232.

10 29 P-H Tax Ct. Mem. 1258 (I960).

11 Id. at 1260 . 
son, an employee.42 The Tax Court found that the payments were made for the personal benefit of the two remaining shareholders rather than for a legitimate corporate purpose and imputed a taxable dividend to them of ten thousand dollars each. ${ }^{43}$

Although the Tax Court did not elaborate on its ruling, it would appear that the failure to find the business purpose bona fide was based on the rationale that a dispute over an issue such as a retirement plan has only incidental effect on corporate operations in that settlement of such a dispute runs primarily to the benefit of the shareholders. ${ }^{44}$ Glenn-Minnich further demonstrates that often the primary concern of a court is in finding a legitimate corporate purpose, for in that case the court treated as incidental the fact that benefit accrued to a relative of a waiving shareholder.45

However, when the family relationship is linked with an elaborate scheme for apparent tax avoidance, a constructive dividend theory can be applied with some facility to thwart such artifices. There has been no such disposition in a waiver of dividends context, but analogous applications of a constructive dividend theory may presage a transplantation into a waiver of dividends context. For example, constructive dividends have been found where a majority shareholder caused a corporation to purchase gasoline from a family partnership at prices in excess of what the corporation paid in purchases from a jobber before the partnership was created. ${ }^{46}$ Refusing to recognize these excess payments by the

${ }^{2}$ Id. at $1262 \cdot 64$.

1s $I d$. at $1268-69$. See note 44 infra.

14 See 29 P-H Tax Ct. Mem. at 1269. A court might, however, reach a contrary result if it should find the retirement plan essential to enable the corporation to continue functioning as a going concern. For example, where it is necessary to attract new key employees or to prevent dissolution, payments by the corporation to a retirement fund might be held to have been made for a bona fide corporate purpose and thus not attributable to the approving shareholders as a constructive dividend. Compare Tucker v. Commissioner, 226 F.2d 177 (8th Cir. 1955); Marjorie N. Dean, 10 T.C. 19 (1948).

${ }_{15} 29 \mathrm{P}-\mathrm{H}$ Tax Ct. Mem. at 1269. The family relationship factor was mentioned by the court in Glenn-Minnich only in its factual statement of the case. Id. at 1260. The court focused primarily upon the business purpose for the corporate payments. Family relationship inay have been one of the many factors which the court considered before holding the two shareholders taxable on the constructive dividend theory, but there was no indication by the court that this factor was of pivotal import in its decision. See also Prunier v. Commissioner, 248 F.2d 818 (Ist Cir. 1957).

${ }^{46}$ Byers v. Commissioner, 199 F.2d 273.74 (8th Cir. 1952), cert. denied, 345 U.S. 907 (1953). In Byers, the controlling shareholder of a trucking corporation in which his wife, nephew, daughter and son held minor stock interests organized a partnership composed of his daughter and son. This partnership then purchased gasoline 
corporation to the partnership as "ordinary and necessary" business expenses, the court held the majority shareholder taxable on this excess on the constructive dividend theory. ${ }^{47}$

Similarly, constructive dividends were found where a husband and wife, who owned respectively seventy-eight per cent and twenty-two per cent of the stock in a can company, set up a realty company in which the husband owned five per cent and the wife ninety-five per cent. ${ }^{48}$ By diverting some of the can company's income to the realty company, ${ }^{49}$ the husband was able to receive the benefit of income taxed at a lower rate since his wife was a lower bracket taxpayer. Because the court found no business purpose behind the arrangement other than the shifting of taxes, the husband was taxed on realty company income as a constructive dividend on the basis of his stock holdings in the can company. ${ }^{50}$

The family relationship principle has not always provided an easy solution for the courts. The frequent identity of interests between a close corporation and its shareholders gives rise to difficulties in determining motives behind shareholder-corporation transactions

from the same jobber who had previously sold to the corporation and resold it to the corporation at a price of two cents more per gallon. Ibid.

"Id. at 275.

Also illustrative of a guise courts have heretofore found to be illegitimate is 58th Street Plaza Theatre, Inc. v. Commissioner, 195 F.2d 724 (2d Cir. 1952). Here a family-owned theatre corporation subleased a theatre to its organizer's wife, who was also a shareholder, at a rent substantially below the anticipated corporate profits. Through this means the excess corporate profits tax was avoided and prospective dividends were siphoned off as income to the wife, whose income was taxed in a lower tax bracket than that of her husband, the corporation's organizer and controlling shareholder. The Second Circuit found the lease to be merely a family arrangement for accomplishing a prospective tax saving and taxed the income received by the wife via the sublease as a dividend to the wife. Id. at 724-25. While the tax avoidance scheme was discredited, the decision seems inconsistent with the result reached by the Service in Rev. Rul. 56-431, 1956-2 CuM. BuLl. 171, and by several courts. See, e.g., Byers v. Commissioner, supra note 46 . To be consistent, the husband should have been taxed under the constructive dividend theory on a pro rata portion of the income diverted to his wife.

However, it is not always necessary to tax the waiving party rather than the beneficiary of the waiver, as in the situation where there is no possibility that the waiving party is attempting to shift the tax burden to a lower bracket taxpayer while retaining control over the property. For an example of a case where the beneficiary of the waiver was properly taxed, see Sachs v. Commissioner, 277 F.2d 879 (8th Cir. 1960).

${ }^{48}$ Helvering v. Gordon, 87 F.2d 663, 664-68 (8th Cir. 1937).

10 This diversion of income was accomplished in accordance with an arrangement between the can company and its supplier whereby "the difference between the price ... at which the tin plate was billed ... and the lower price for which it was actually purchased was rebated to the Wallace Realty Company." Id. at 664.

${ }^{50}$ Id. at 666-68. 
which result in distinct benefits to both the corporation and relatives of a dominant shareholder. ${ }^{51}$ As a result, courts have not primarily concerned themselves with motive or intent; rather, they have utilized an objective test which focuses upon the distribution of the net economic benefit.52 Thus, while the existence of the family relationship may initially invite close judicial scrutiny of a transaction, the above cases and precedent in analogous areas indicate that the mere existence of this relationship between the waiving and benefited shareholders may not be sufficient to invoke the constructive dividend doctrine. ${ }^{53}$ The family relationship appears to be but one factor negating the existence of a bona fide business purpose. Where the waiver of future dividends can be shown to have independently produced a significant corporate benefit, the family relationship arguably becomes immaterial. ${ }^{54}$ At least where the related shareholders occupy substantially adverse business interests, the family relationship may no longer serve its purpose as an indicator that a tax avoidance scheme may be involved. ${ }^{55}$ To this extent, the problem of a waiver of future dividends to a related shareholder for a business purpose, left unresolved by Revenue Ruling 65-256, is not insoluble.

On its face, Revenue Ruling 65-256 seems to indicate approval

\footnotetext{
E1 Lewis v. Commissioner, 176 F.2d 646, 649-50 (1st Cir. 1949) (dictum); see, e.g., Nelson v. Commissioner, 203 F.2d 1 (6th Cir. 1953).

52 E.g., Sachs v. Commissioner, 277 F.2d 879, 882-83 (8th Cir. 1960); Helvering v. Gordon, 87 F.2d 663, 666 (8th Cir. 1937). See note 27 supra and accompanying text.

What constitutes a "direct" or "substantial" benefit to the corporation is probably not capable of clear delineation. Determination on a case-by-case basis seems to be the only practical approach, although findings of an adequate business purpose in analogous tax areas would seem to have precedential effect for the waiver of future dividends situation. In this connection see, e.g., Tucker v. Commissioner, 226 F.2d 177 (8th Cir. 1955); Fred F. Fischer, 16 P-H Tax Ct. Mem. 456 (1947).

s3 See, e.g., Nelson v. Commissioner, 203 F.2d I (6th Cir. 1953).

st An examination of the cases indicates that a dividend has not been deemed constructively received if the evidence suggests a more substantial benefit to the corporation than to a controlling shareholder's relative, or cven if evidence suggests an equal benefit to both. See, e.g., Fred F. Fischer, 16 P-H Tax Ct. Mem. 456 (1947). However, if the benefit to the corporation is insignificant or incidental and runs primarily to relatives of a dominant shareholder, then any distribution by the corporation necessary to the accomplishment of the transaction will be taxed to the waiving shareholder. See, e.g., Minnie F. Lasker, 21 P-H Tax Ct. Mem. 40 (1952).

"5 See note 29 supra. The existence of the family relationship is more likely to be material where the legitimacy of the business purpose becomes more questionable. $A$ related question might further arise as to the extent the benefited relative is a natural object of the taxpayer's bounty. If that relative is, for example, the taxpayer's nephew, and the taxpayer has three sons who receive no benefit from a given transaction, suspicion as to its bona fides might not arise to the same degree as if a son of the taxpayer were the "benefited" party.
} 
of decisions which deny application of the constructive dividend doctrines where the corporate benefit is clear and the benefits to relatives of a waiving shareholder are only incidental. There is still no indication as to whether the Service would tax "dividends waived" for a bona fide business purpose but resulting in a substantial benefit to non-waiving "related" shareholders. ${ }^{56}$ Adherence to the family relationship rule, however, suggests a recognition that transactions between corporations and shareholders which benefit a shareholder's relative have in the past been so subject to fraud and attempted tax avoidance that they are inherently suspect. Clarification of the requisites for an appropriate business purpose and delineation of guidelines suggesting the extent to which a family relationship will result in tax liabilities when future dividends are waived would thus seem an appropriate area for IRS determination.

so The question of who is a "related person" for purposes of the constructive dividend doctrine has not been answered by the code or the courts. Sections 318 and 544 of the Internal Revenue Code relate to constructive stock ownership rules and suggest some analogies. On the other hand, the family relationship rule might be more appositely applied whenever the relationship is sufficiently close justifiably to infer the existence of family cooperation. See note 4 supra. 